\title{
Discussion on the Teaching Mode Innovation of Environmental Art Design Major based on OBE Concept
}

\author{
Xin Zhang
}

Zibo Vocational Institute Shandong, Zibo 255300, China

\begin{abstract}
This paper explores the innovative ways of teaching mode of environmental art design major under the concept of OBE. Through theoretical elaboration, combined with the understanding of literature and practical work experience, it innovates from three aspects of teaching concept, teaching system and training objectives, and establishes an innovative teaching system.
\end{abstract}

Keywords: OBE concept; Environmental art design; Innovation of teaching mode; Practical personnel

Publication date: November, 2020

Publication online: 30 November, 2020

"Corresponding author: Xin Zhang, martian 868 (a)163.com

\section{Introduction}

OBE education concept is the latest education concept in the world. The emergence of this education concept provides a new direction for international teaching. With the reform and development of national education, the teaching mode has gradually changed, and the talent training content has changed to application-oriented talents, so as to cultivate applied talents who can meet the social needs. Wang Xiaoli ${ }^{[1]}$ in the "Internet plus" era, the innovation of teaching mode of calligraphy course in college and University, puts forward the Internet plus mode of innovation, changing the way of teaching in the classroom, optimizing the classroom teaching by using micro lesson, moody class and flipped classroom. The research of Zhu xiongxuan $^{[2]}$ shows that the innovative teaching mode needs to be carried out in three steps. The first step is modular teaching to reduce the basic differences between students. The second step is to combine theory with practice teaching. The third step is to integrate theory and practice teaching into relevant professional teaching to realize mixed teaching, so as to cultivate excellent innovative and mixed talents for the country; Niu shujiao ${ }^{[3]}$ put forward a teaching mode of studio system, and analyzed the feasibility and implementation process of studio system teaching mode to cultivate art design related professionals; According to Huang Yong ${ }^{[4]}$, there are three disadvantages in the current environmental art design major, including unreasonable curriculum, lack of teachers, lack of practical teaching and so on; Chen Jiexian $^{[5]}$ through the research on the application of micro class in environmental art major, elaborated the use process of micro class, and concluded that the use of micro class in environmental art design teaching can not only improve the learning effect of students, but also enhance the teaching strength of teachers. This paper first points out the significance of OBE concept for the teaching of environmental art design major, and focuses on the reform of teaching mode of environmental art design major under the OBE concept, so as to cultivate applied and innovative talents for the society.

\section{The significance of OBE education concept to the teaching reform of environmental art design major}

OBE philosophy of education emphasizes ability training rather than theoretical knowledge. In the era of increasingly civilized human society, the focus of education has been shifted to the cultivation of applied technical talents, and it pays attention to students receiving systematic, comprehensive and 
specialized knowledge and skills training in school, so as to improve their comprehensive ability to meet the needs of the company and society. How to cultivate the applied talents needed by enterprises and society has become a key issue in the research and reform of many universities. The interdisciplinary nature of environmental art design is very strong, and it is highly comprehensive. In addition to the knowledge connection with design specialty, it is also closely related to many marginal disciplines. Under the guidance of OBE education concept, it is of great significance to carry out educational reform, change teaching mode and innovate teaching methods.

\section{Teaching reform path of environmental art design major under the concept of OBE Education}

Following the OBE education concept, aiming at the prominent problems of environmental art design specialty, teachers should change their teaching concepts, establish a reasonable curriculum teaching system, and make clear the goal of cultivating professional talents with the characteristics of the times, and carry out teaching innovation and reform as soon as possible.

\subsection{Teachers of environmental art and design must renew their educational ideas}

The concept of OBE education is a high-level teaching concept that has appeared for a long time, but it has produced rich educational achievements. Therefore, according to the needs of the times, it is the best choice to use it to guide teachers' education concept. Under the influence of OBE education concept, teachers have changed the traditional education concept, pay attention to the educational results, change the role of students, constantly cultivate and shape the personality of students, and stimulate students' imagination and creativity. In order to speed up the OBE education concept rooted in the teacher education thought, universities can hold teacher training classes, create a platform for the exchange of OBE education ideas, and promote the application of OBE education concept in environmental art design specialty.

3.2 Scientific teaching system should be established in Environmental Art Design Specialty

Due to the influence of OBE education concept, the reform corresponding to the development of environmental art design specialty should be carried out. Teachers should change their teaching concepts, students should participate in teaching practice, the classroom atmosphere should be active, the curriculum objectives should be layered, the ultimate goal should be comprehensive, and the teaching members should meet the standards. In the course design link, teachers should follow the teaching concept of OBE as a guide, and should have a link to students' teaching practice. Through the development of specific classroom assignments, students can actively participate in it, and various design competitions can improve students' practical application skills. It enhances students' sense of teamwork and lays a good foundation for employment.

Project introduction (practice project introduction) breaks the inherent curriculum structure of discipline system, develops curriculum modules according to "environmental art project design process", realizes the requirement of "dual subjects", and establishes the curriculum system of "integrating and modulating the dual subjects based on the project design process". Integrate and order the training content according to the actual work task and workflow. Project work is used to lead the organization of education and design the work of environmental art course to realize the integration of teaching, learning and project.

Task oriented education strengthens and retains learners' achievement motivation through teacher led or student-centered tasks. Achievement motivation is the motivation system for students to study and finish homework. Task is the bridge of learning. It is not only the teacher who drives the students through the task to stimulate the learning motivation, but also depends on the learners' own efforts to actively stimulate the motivation to pursue achievement. Therefore, the task is not static and isolated, but refers to the evolution process from the external to the internal, which aims to form the achievement motivation of learners, that is, the generation of achievement motivation. Task drive is the process of transferring from internal drive of task to synchronous drive.

"Double subject" adopts the Task-oriented Teaching Method to realize the students' subjectivity in the classroom. The so-called task center is to provide students with homework that can be 
completed independently, while teachers provide necessary guidance for students in the process of completing. This method not only reflects the dominant position of teachers, but also gives full play to the subjective initiative of students, reflecting the dominant position of students. It is in line with the characteristics of strong operability of art design courses, and improves the practical ability of students.

\subsection{Environmental art design major should take innovative applied talents as the training goal}

According to the OBE education concept, the beneficiaries of cultivating applied talents of environmental art design are the government, schools, employers, students and parents. With the cultivation of innovative talents, the employment rate of college students has been significantly improved, the investment of parents has been reasonably recovered, enterprises have obtained high-efficiency talents, alleviated the social employment pressure and lightened the government burden. Therefore, we combine OBE education concept to cultivate innovative applied talents of environmental art design, which benefits the country and the people.

We will integrate the maker space into the education industry base, and implement the education integration training mechanism of "specialty + production + enterprise". Focus on the industrial chain, focus on technology research, determine the main line of resource integration, activate the list of technical equipment resources, gather talents, innovate and develop, and get a win-win mode. Based on the concept of OBE education, a shared and innovative teaching mode of environmental art design is formed, which integrates internship training, entrepreneurship incubation, technology research and social training, which is symbiotic and mutually integrated. Relying on the basis of educational innovation, taking project practice as the core, students' innovative thinking development as the driving force, and industry, enterprise and school cooperation as the driving force, the whole educational organizational structure is optimized, so as to enhance the innovation ability and entrepreneurship through professional training courses. The combination of production, teaching and research can achieve the goal of talent development and innovation and win-win entrepreneurship.

\section{Summary}

To sum up, we should innovate from three aspects: teaching concept, teaching methods and teaching objectives. We should cultivate innovative and applied talents by using OBE concept; Through the introduction of practice project, change the main body of the classroom. Finally, the innovation and reform of teaching mode of environmental art design specialty is realized.

\section{References}

[1] Wang XL. Innovation of teaching mode of calligraphy course in art and design major in the era of Internet plus[J]. Industry and Technology Forum, 2020, 19 (19): 162-163.

[2] Zhu XX. the innovation path of art design curriculum in Higher Vocational Colleges under the mixed teaching mode [J]. Research and development of food, 2020, 41 (15): 242.

[3] Niu J, Zhang MM. Analysis and implementation of studio teaching mode for environmental art and Design Specialty in Higher Vocational Colleges [J]. Comparative study on cultural innovation, 2020, April (22): 52-54.

[4] Huang Y. Research on studio teaching mode of environmental art design specialty in Colleges and universities [J]. Science and technology economy guide, 2020, 28 (21): 1111-112.

[5] Chen JX. Construction and application of micro course for environmental art design specialty in Higher Vocational Colleges under the mixed teaching mode [J]. Xueyuan, 2020, 13 (18): 130-131. 